\title{
Comparison between Response Spectrum and Time History Method of Dynamic Analysis of Concrete Gravity Dam
}

\author{
Aarti Baburao Rampure, Madhuri Nilesh Mangulkar \\ Department of Civil Engineering, Mahatma Gandhi Mission's Jawaharlal Nehru Engineering College, \\ Aurangabad, India \\ Email: rampureaarti91@gmail.com, mangulkarm@yahoo.com
}

Received 18 February 2016; accepted 22 April 2016; published 25 April 2016

Copyright (C) 2016 by authors and Scientific Research Publishing Inc.

This work is licensed under the Creative Commons Attribution International License (CC BY). http://creativecommons.org/licenses/by/4.0/

\begin{abstract}
Dam structure built to store water has failed with resulting loss of life, social, economic and environmental losses due to seismic vibrations. These vibrations are dynamic in nature. These vibrations must be reduced with proper application of engineering principles and for estimating the behavior of concrete gravity dam dynamic analysis plays an extraordinary role. This paper presents the dynamic time history analysis and response spectrum method of a concrete gravity dam by using STAAD-PRO. Here Finite Element Approach is used to analyze the dam. A concrete gravity dam model is prepared in STAAD-PRO to perform the time history analysis and response spectrum analysis and a comparison is done between both these methods. Concrete gravity dam is a large structure which retains a very large amount of water on its upstream side and it is very crucial for a dam to survive against vibrations of earthquake. So it is a matter of study to check the behaviour of a dam during and after the application of the loading.
\end{abstract}

\section{Keywords}

Concrete Gravity Dam, Time History Method, Response Spectrum Method, IS Code 6512:1984, STAAD-PRO

\section{Introduction}

Dams have contributed to the development of civilization for a long time. They will continue to keep their importance in satisfying the ever increasing demand for power, irrigation and drinking water, the protection of man, property and environment from catastrophic floods, and in regulating the flow of rivers. Gravity dams are very 
popular in these days. The dam body is designed in such a way that to withstand water pressure, silt pressure, uplift pressure with weight of the dam [1]. There are several factors affecting the dynamic response of concrete gravity dams to earthquake ground motions. Some of them are the interaction of the dam with the foundation rock and water in reservoir, sediment accumulated at the bottom of reservoir, and non-linear behavior of dam concrete. STAAD-PRO is primarily designed to provide support for learning the principles of structural stability evaluation of gravity dams. It can also be used for research and development on stability of gravity dams. In adopting several worldwide published dam safety guidelines, a large number of modelling options have been implemented regarding (a) crack initiation and propagation, (b) effects of drainage and cracking under static, seismic, and post-seismic uplift pressure conditions, and (c) safety evaluation formats [2]. The basic objective of seismic design is to provide structures with appropriate safety margins against failure when it is subjected to strong earthquakes. In the finite element method, the solution region is considered as built up of many small, interconnected sub regions called finite elements. Since it is very difficult to find the exact response of complicated structure under specified loading conditions, the structure is approximated as composed of several pieces in the finite element model [3]. Concrete dams are among high importance structures, regarding requirements for continuous service during their lifetime, and catastrophic effects in cases of probable dam failure. Therefore, the safety of these structures should be investigated quite critically by logical and precise methods. With the improvement of knowledge in earthquake engineering and the development of more reliable methods for estimating earthquake magnitudes at different sites, methods for the seismic analysis of structures are being developed that include the effects of more complicated parameters in the evaluation and seismic hazard analysis of structures.

The main objective of this paper is to study the seismic behaviour of concrete gravity dam. According to the Indian standard code of practice dynamic analysis shall be done for dam with height greater than $100 \mathrm{~m}$ [4]. In this paper, two dams of height below the $100 \mathrm{~m}$ that is $70 \mathrm{~m}$ and $90 \mathrm{~m}$ and dam of height above $100 \mathrm{~m}$ that is $110 \mathrm{~m}$ have been analyzed by using the response spectrum and time history analysis, based on IS codes and also to cross check whether dynamic analysis is necessary or not for the dam of height below $100 \mathrm{~m}$. And the results obtained are compared eventually to determine the structural performance of concrete gravity dam. Response spectrum and time history analysis play an extraordinary role. In time history analysis time acceleration as an input data with acceleration with respect to time. Time history analysis provides the various mode shapes and direction of structure which varies as per specified time-acceleration function and these mode shapes varies as dynamic structural response under various loading. After the dynamic analysis it can be easily predicted whether the structure will survive or not under the effect of seismic vibration. The details of the study and its result are described briefly in the following section of the paper.

\section{Parametric Details of Model}

The three different heights of the dam of 70 m, 90 m and 110 m of models are shown in Figures 1-3 respectively. Tables 1-3 represents all the basic specification required for the analysis of concrete gravity dam [5] [6].

\section{Table 1. Specification of models for $70 \mathrm{~m}$ height of the dam.}

\begin{tabular}{cc}
\hline Type of Structure & Concrete Gravity Dam \\
\hline Seismic Zone & V, As per IS 1893 Part I, Z $=0.36$ \\
Importance Factor & For all dams $=1$ \\
Rock and Hard Soil Site Factor & Hard Soil = 1 \\
Damping Ratio & 0.05 \\
Height of the Dam & $70 \mathrm{~m}$ \\
Length of Dam & Unit length of dam is considered \\
Base Width of Dam & $45 \mathrm{~m}$ \\
Specific Weight of Concrete & $25 \mathrm{kN} / \mathrm{m}^{3}$ \\
Poisson Ratio of Concrete & 0.17 \\
Modulus of Elasticity of Concrete & $21.718 \mathrm{~N} / \mathrm{mm}^{2}$ \\
\hline
\end{tabular}




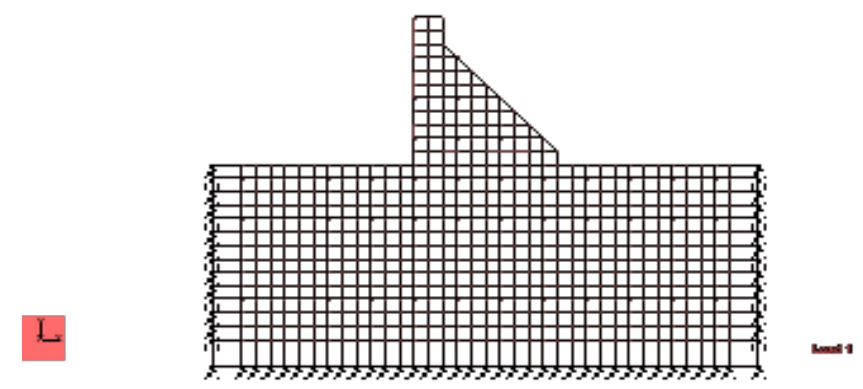

Figure $1.70 \mathrm{~m}$ height of the dam.

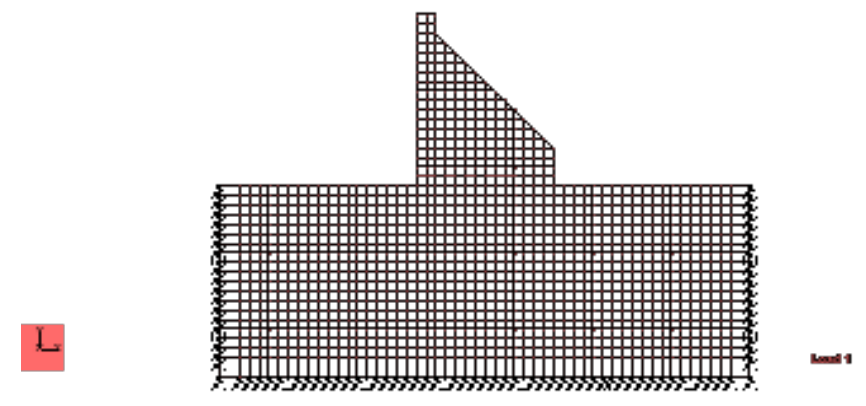

Figure 2. $90 \mathrm{~m}$ height of the dam.

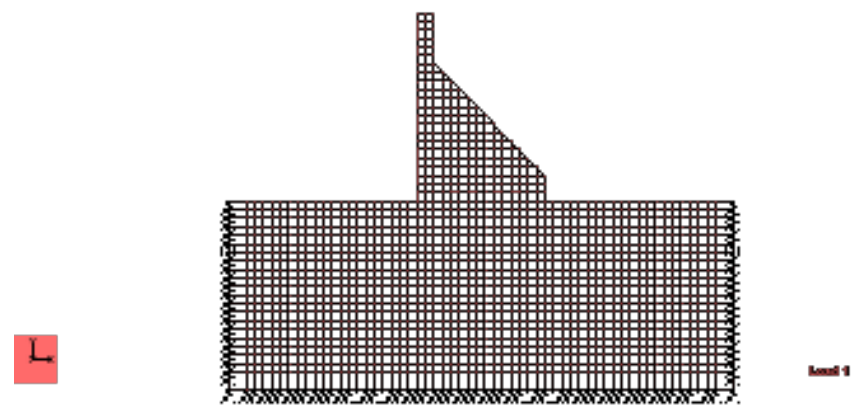

Figure 3. $110 \mathrm{~m}$ height of the dam.

Table 2. Specification of models for $90 \mathrm{~m}$ height of the dam.

\begin{tabular}{cc}
\hline Type of Structure & Concrete Gravity Dam \\
Seismic Zone & V, As per IS 1893 Part I, Z = 0.36 \\
Importance Factor & For all dams = 1 \\
Rock and Hard Soil Site Factor & Hard soil = 1 \\
Damping Ratio & 0.05 \\
Height of the Dam & $90 \mathrm{~m}$ \\
Length of Dam & Unit length of dam is considered \\
Base Width of Dam & $70 \mathrm{~m}$ \\
Specific Weight of Concrete & $25 \mathrm{kN} / \mathrm{m}^{3}$ \\
Poisson Ratio of Concrete & 0.17 \\
Modulus of Elasticity of Concrete & $21.718 \mathrm{~N} / \mathrm{mm}^{2}$ \\
\hline
\end{tabular}


Table 3. Specification of models for $110 \mathrm{~m}$ height of the dam.

\begin{tabular}{cc}
\hline Type of Structure & Concrete Gravity Dam \\
\hline Seismic Zone & V, As per IS 1893 Part I, Z =0.36 \\
Importance Factor & For all dams $=1$ \\
Rock and Hard Soil Site Factor & Hard soil = 1 \\
Damping Ratio & 0.05 \\
Height of the Dam & $110 \mathrm{~m}$ \\
Length of Dam & Unit length of dam is considered \\
Base Width of Dam & $80 \mathrm{~m}$ \\
Specific Weight of Concrete & $25 \mathrm{kN} / \mathrm{m}^{3}$ \\
Poisson Ratio of Concrete & 0.17 \\
Modulus of Elasticity of Concrete & $21.718 \mathrm{~N} / \mathrm{mm}^{2}$ \\
\hline
\end{tabular}

\section{Methodology}

This paper presents the dynamic time history analysis and response spectrum analysis of a concrete gravity dam by using STAAD-PRO. A concrete gravity dam of different heights $70 \mathrm{~m}, 90 \mathrm{~m}$ and $110 \mathrm{~m}$ model is prepared in STAAD-PRO to perform the time history analysis and response spectrum analysis. Finite element has been widely used in the analysis of concrete gravity dams with a defined approach as presented in this paper. Time history is basically a method of seismic analysis for the simulation of an earthquake motion. It is an ultimate tool to study the dynamic response of a structure. In this paper gives time history analysis by using time-acceleration data as input function and then performance of the gravity dam is evaluated with various mode shapes and time-acceleration results. In Response Spectrum method, results are obtained by using medium soil factors and other criteria's from IS 1893 are used and the results are compared in both the cases. Various basic loads and load combinations are used in analysis of concrete gravity dam according to IS 6512:1984 [4]. Table 4 represents basic loads and load combinations used during the analysis.

\section{Results and Discussion}

Table 5 represents the normal, shear, principle stresses for $70 \mathrm{~m}$ height of the dam structure by both the methods.

Table 6 represents the normal, shear, principle stresses for $90 \mathrm{~m}$ height of the dam structure by both the methods.

Table 7 represents the normal, shear, principle stresses for $110 \mathrm{~m}$ height of the dam structure by both the methods.

\section{Conclusions}

a) Dams being very important structure shall be designed with very great accuracy. The section of gravity dam should be chosen in such a way that it is the most economic section and satisfies all the conditions and requirements of stability.

b) STAAD-PRO is the most convenient and less tedious for dynamic analyses and it provides a computing environment to investigate modelling assumptions and computational processes related to the static and seismic structural stability of gravity dams.

c) A full time history will give the response of a structure over time during and after the application of a load and Response-spectrum analysis (RSA) is a linear-dynamic statistical analysis method which measures the contribution from each natural mode of vibration to indicate the likely maximum seismic response of an essentially elastic structure.

d) From results we can conclude that it is necessary to analyse the structure by dynamic analysis of both these method for below the height of dam $100 \mathrm{~m}$ and above the height of dam $100 \mathrm{~m}$. 
Table 4. Basic loads and load combinations used during the analysis.

\begin{tabular}{cc}
\hline Sr. no & Basic loads and load combinations \\
\hline 1 & Self weight of dam (DL) \\
2 & Water pressure (WP) \\
3 & Silt pressure (SP) \\
4 & Uplift pressure (UP) \\
5 & Earthquake pressure (EQL) \\
6 & Time history loads (TH) \\
7 & Response spectrum load (RSM) \\
8 & $(\mathrm{DL}+\mathrm{WP}+\mathrm{SP}+\mathrm{UP}+\mathrm{EQL}+\mathrm{TH})$ \\
9 & $(\mathrm{DL}+\mathrm{WP}+\mathrm{SP}+\mathrm{UP}+\mathrm{EQL}+\mathrm{RSM})$ \\
\hline
\end{tabular}

Table 5. $70 \mathrm{~m}$ height of the dam.

\begin{tabular}{|c|c|c|c|c|c|c|c|}
\hline Sr. no & Output & \multicolumn{3}{|c|}{ Response spectrum } & \multicolumn{3}{|c|}{ Time history } \\
\hline \multirow[t]{2}{*}{1.} & \multirow[t]{2}{*}{ Solid centre stresses } & $\begin{array}{l}\text { Normal } \\
\left(\mathrm{N} / \mathrm{mm}^{2}\right)\end{array}$ & $\begin{array}{c}\text { Shear } \\
\left(\mathrm{N} / \mathrm{mm}^{2}\right)\end{array}$ & $\begin{array}{l}\text { Principal } \\
\left(\mathrm{N} / \mathrm{mm}^{2}\right)\end{array}$ & $\begin{array}{l}\text { Normal } \\
\left(\mathrm{N} / \mathrm{mm}^{2}\right)\end{array}$ & $\begin{array}{c}\text { Shear } \\
\left(\mathrm{N} / \mathrm{mm}^{2}\right)\end{array}$ & $\begin{array}{l}\text { Principal } \\
\left(\mathrm{N} / \mathrm{mm}^{2}\right)\end{array}$ \\
\hline & & -6.945 & 0.450 & -2.175 & -6.830 & 0.325 & -1.915 \\
\hline 2. & Solid corner stresses & -9.299 & 1.210 & -5.808 & -8.233 & 1.111 & -4.503 \\
\hline
\end{tabular}

Table 6. $90 \mathrm{~m}$ height of the dam.

\begin{tabular}{|c|c|c|c|c|c|c|c|}
\hline Sr. no & Output & \multicolumn{3}{|c|}{ Response spectrum } & \multicolumn{3}{|c|}{ Time history } \\
\hline \multirow{2}{*}{1.} & Solid centre stresses & $\begin{array}{l}\text { Normal } \\
\left(\mathrm{N} / \mathrm{mm}^{2}\right)\end{array}$ & $\begin{array}{l}\text { Shear } \\
\left(\mathrm{N} / \mathrm{mm}^{2}\right)\end{array}$ & $\begin{array}{l}\text { Principal } \\
\left(\mathrm{N} / \mathrm{mm}^{2}\right)\end{array}$ & $\begin{array}{l}\text { Normal } \\
\left(\mathrm{N} / \mathrm{mm}^{2}\right)\end{array}$ & $\begin{array}{c}\text { Shear } \\
\left(\mathrm{N} / \mathrm{mm}^{2}\right)\end{array}$ & $\begin{array}{l}\text { Principal } \\
\left(\mathrm{N} / \mathrm{mm}^{2}\right)\end{array}$ \\
\hline & & -4.058 & 1.451 & -1.701 & -4.032 & 1.241 & -1.699 \\
\hline 2. & Solid corner stresses & -9.316 & 2.905 & -5.149 & -9.288 & 2.818 & -5.115 \\
\hline
\end{tabular}

Table 7. $110 \mathrm{~m}$ height of the dam.

\begin{tabular}{|c|c|c|c|c|c|c|c|}
\hline Sr. no & Output & \multicolumn{3}{|c|}{ Response spectrum } & \multicolumn{3}{|c|}{ Time history } \\
\hline \multirow{2}{*}{1.} & \multirow{2}{*}{ Solid centre stresses } & $\begin{array}{c}\text { Normal } \\
\left(\mathrm{N} / \mathrm{mm}^{2}\right)\end{array}$ & $\begin{array}{c}\text { Shear } \\
\left(\mathrm{N} / \mathrm{mm}^{2}\right)\end{array}$ & $\begin{array}{l}\text { Principal } \\
\left(\mathrm{N} / \mathrm{mm}^{2}\right)\end{array}$ & $\begin{array}{c}\text { Normal } \\
\left(\mathrm{N} / \mathrm{mm}^{2}\right)\end{array}$ & $\begin{array}{c}\text { Shear } \\
\left(\mathrm{N} / \mathrm{mm}^{2}\right)\end{array}$ & $\begin{array}{l}\text { Principal } \\
\left(\mathrm{N} / \mathrm{mm}^{2}\right)\end{array}$ \\
\hline & & -107.711 & -2.032 & 16.608 & -98.75 & -1.036 & 14.315 \\
\hline 2. & Solid corner stresses & 138.321 & -5.337 & -31.371 & 135.623 & -4.335 & -30.147 \\
\hline
\end{tabular}

e) The main advantage is that stress variation through the dam body can be studied carefully and the slopes can be designed according to the stress pattern.

f) Thus it is necessary to analyze the structure by considering both the methods. And structure should be designed for maximum values.

\section{References}

[1] Garg, S.K. (2013) Irrigation Engineering and Hydraulic Structure. Khanna Publishers, 77-79.

[2] Subramani1, T. and Ponnuvel, D. (2012) Seismic and Stability Analysis of Gravity Dams Using STAAD-PRO. International Journal of Engineering Research and Development, 1, 44-54.

[3] Varghese, B., Saju, A. and John, S. (2008) Finite Element Analysis of Arch Dam. IJRET: International Journal of Re- 
search in Engineering and Technology, 6, 55-58.

[4] I.S.6512-1984 Criteria for Design of Solid Gravity Dams. B.I.S. New Delhi.

[5] I.S.1893-1984 Criteria for Earthquake Resistant Design of Structures. Bureau of Indian Standards, New Delhi.

[6] BIS (2002) IS 1893 (Part 1) —2002: Indian Standard Criteria for Earthquake Resistant. 